\title{
Comparative study on the influence of rare earth ions doping in $\mathrm{Bi}_{0.6} \mathrm{Sr}_{0.4} \mathrm{FeO}_{3}$ nanomultiferroic system
}

\author{
M. A. Ahmed ${ }^{1}$, N. Okasha ${ }^{2}$, M.M. Abdelaal' ${ }^{2}$, M. Ayman ${ }^{3}$ \\ 1. Material Science Lab. (1) Physics Department, Faculty of Science, Cairo University, Giza, \\ Egypt. \\ 2. Physics Department, Faculty of Girls, Ain Shams University, Cairo, Egypt. \\ 3. Physics Department, German University (GUC), Cairo, Egypt.
}

\begin{abstract}
We report a comparative study of rare-earth ions substituted $\mathrm{Bi}_{0.6} \mathrm{Sr}_{0.4} \mathrm{FeO}_{3}$ (BSFO) crystal for; BSFO, $\mathrm{Bi}_{0.57} \mathrm{Sr}_{0.4} \mathrm{Y}_{0.03} \mathrm{FeO}_{3}, \mathrm{Bi}_{0.57} \mathrm{Sr}_{0.4} \mathrm{Nd}_{0.03} \mathrm{FeO}_{3}, \mathrm{Bi}_{0.57} \mathrm{Sr}_{0.4} \mathrm{Ce}_{0.03} \mathrm{FeO}_{3}$, and $\mathrm{Bi}_{0.57} \mathrm{Sr}_{0.4} \mathrm{La}_{0.03} \mathrm{FeO}_{3}$, respectively. The samples were successfully synthesized using flash autocombustion reaction. $\mathrm{X}$ ray diffraction analysis reveals that the crystal structure is rhombohedral and a clear hexagonal grain growth habit is seen by FESEM microstructure. The doping of BSFO improved the magnetic properties specially $\mathrm{Y}^{3+}, \mathrm{Nd}^{3+}$ ions. While $\mathrm{Ce}^{3+}$ improved the electrical conductivity. We argue that the addition of RE is likely to suppress the spiral spin modulation and at the same time increase the canting angle which favors the enhanced ferromagnetism.
\end{abstract}

Keywords: Rare earth ions, Multiferroics, Bismuth ferrite, flash autocombustion; Magnetic properties, Electrical properties.

\section{Introduction}

Multiferroic materials are single phase materials exhibiting two or more ferroic features such as ferromagnetism, ferroelectricity, or ferroelasticity effects. Recent resurgence of research interest for multiferroic (Jiang et al., 2009, Hunpratub et al., 2009, Zhang et al., 2009, Lahmar et al., 2009) materials revived the possibility of strong coupling between the magnetic and ferroelectric order parameters of some promising materials and are likely to be used around room temperature (RT) for possible device design and applications specially in frontier field of spintronic (Wang et al., 2003) devices, sensor, multiple state memory elements (Wang et al., 2006), electric field controlled ferromagnetic resonance devices, and transducers with magnetically modulated piezoelectricity (Hill, 2000). $\mathrm{BiFeO}_{3}(\mathrm{BFO})$ is one of the very few known magnetoelectric system that exhibits antiferromagnetic ordering $\left(\mathrm{T}_{\mathrm{N}} \approx 380^{\circ} \mathrm{C}\right)$ and ferroelectric behavior with high ferroelectric Curie temperature $\left(\mathrm{T}_{\mathrm{C}} \approx 830^{\circ} \mathrm{C}\right)$ (Eerenstein et al., 2006).

Corresponding author: N. Okasha; naokmo@yahoo.com

Physics Department, Faculty of Girls, Ain Shams University, Cairo, Egypt

Tel, Fax no: 02035693738 Country code: 11722 j 
It is well documented (Smolenskii et al., 1982) that due to canting of Fe sub-lattice moment; BFO shows the presence of weak magnetism. It is the primary goal of the researchers over the globe to improve the desired magnetic properties, without altering the ferroelectric properties of the original BFO materials system. To address the issue of enhancing desired magnetic property specially aiming towards ferromagnetic property, a suitable doping in BFO might be the right approach (Bai et al., 2005, Ederer et al., 2005,Lee et al., 2005) to tailor this material in which the linear magneto-electric coupling would exist (Singh et al., 2008). It has also been suggested that the spiral spin structure can be changed with the application of a higher magnetic field (Sosnowska et al., 1982), epitaxial constraint (Cheong et al., 2007) and doping (Bai et al., 2005). As far as doping in BFO is concerned, one way of doping is by doping of BFO with rare earth elements (Ederer et al., Lee et al., 2005) which are promising to enhance multiferroics properties.

For the past few decades, ferroelectric materials have received a great amount of interests because of their various uses in many applications such as nonvolatile ferroelectric random access memories (NVFRAM), dynamic random access memories, sensors and micro actuators (Uchino, 2000). A crystal is said to be ferroelectric when it possesses at least two equilibrium orientations of the spontaneous polarization vector in the absence of an external electric field, and the spontaneous polarization can be switched between those orientations by an electric field. The polar character of the orientation states should represent an absolutely stable configuration in a null field (Lines et al., 1977).

Among the thirty-two crystal classes, eleven of them are characterized by the existence of a center of symmetry. The remaining twenty-one crystal classes do not have a center of symmetry. Thus, it is possible for the 21 groups to (i) have one or more polar axes, and (ii) possess odd-rank tensor properties. The only exception is the group 432, which lacks a center of symmetry, but has other symmetry operations that destroy polarity. All non-centrosymmetric point groups exhibit piezoelectric effect that is defined by a change in electric polarity under applied stress, and vice versa. Out of the twenty piezoelectric classes, ten possess a unique polar axis, the spontaneous polarization of which depends on temperature. This is called the pyroelectric effect. Ferroelectric crystals belong to the pyroelectric family, which in addition has a spontaneous polarization can be reversed by external electric field, i.e. more than one equivalent direction for Ps (Mukherjee et al., 2014).

Among all ferroelectric materials, the most extensively studied and widely used are the perovskite. A perfect perovskite structure has a general formula of $\mathrm{ABO}_{3}$, where A represents a divalent or trivalent cation, and B is typically a tetravalent or trivalent cation.

Rare earth (RE) elements possess large magnetic moments, large magnetocrystalline anisotropy and very large magnetostriction at low temperatures due to the localized nature of $4 f$ electrons. Rare earth-iron based compounds $\left(\mathrm{RFe}_{2}\right)$ are known to exhibit very large magnetostriction and these compounds are employed as active elements in several magnetostrictive transducers. However, the large conductivity of these compounds limits the usage of the transducers to low frequencies (few $\mathrm{kHz}$ ).

Several authors tried to improve the magnetic properties of BFO by suitably doping with rare earth elements like $\mathrm{La}^{3+}, \mathrm{Nd}^{3+}, \mathrm{Gd}^{3+}, \mathrm{Sm}^{3+}, \mathrm{Pr}^{4+}$ (Gruverman et al., 2006, Ahn et al., 2004, Slimani Tlemcani et al., 2015) where the dopants produce magnetization by sup- pressing the spiral spin structure of BFO. ( $\mathbf{L i}$ et al., 2007) found that $\mathrm{LaFeO}_{3}$ materials exhibited higher photocatalytic activity. Following this, $\mathrm{BiFeO}_{3}$ materials were shown to exhibit visible light photocatalytic properties (Gao et al., 2007). 
In this paper, we report the structural, morphological and multiferroic properties of BSFO and RE-modified BSFO nanomultiferroics synthesized by flash autocombustion method to opens a new era of applications.

\section{Experimental techniques}

\section{2. a. Samples preparation}

$\mathrm{Bi}_{1-\mathrm{x}-\mathrm{y}} \mathrm{Sr}_{\mathrm{x}} \mathrm{RyFeO}_{3} ; \mathrm{x}=0.4$ and $\mathrm{y}=0.03$ multiferroic powders were synthesized by using flash autocombustion reaction (Ahmed et al., 2008). The main advantage of combustion synthesis among many wet methods is that it offers a unique route via a highly exothermic redox reaction between metal nitrates and an organic fuel to produce metal oxides with stoichiometric ratio very near to that chemically mentioned. This method produces a homogenous product in a short time without the use of expensive high temperature furnaces. Analytical grade Bismuth Nitrate; [ $\mathbf{B i}\left(\mathrm{NO}_{3}\right)_{3}$. $\mathbf{5 H}_{2} \mathrm{O}$ ], Strontium Nitrate; $\mathrm{Sr}\left(\mathrm{NO}_{3}\right)_{2}$, Iron Nitrate; $\mathbf{F e}\left(\mathrm{NO}_{3}\right)_{3} \cdot \mathbf{9 H}_{2} \mathrm{O}$, different rare earth metal ions ( $\mathrm{R}$ ) as Lanthanum nitrate; $\mathbf{L a}\left(\mathbf{N O}_{3}\right)_{3}$, Yttrium nitrate $\mathbf{Y}\left(\mathbf{N O}_{\mathbf{3}}\right)_{3}$, Cerium nitrate; $\mathbf{C e}\left(\mathbf{N O}_{3}\right)_{3}$, Neodynium nitrate; $\mathbf{N d}\left(\mathbf{N O}_{3}\right)_{3}$, and Urea; $\mathbf{C O}\left(\mathbf{N H}_{2}\right)_{2}$ that acts as a fuel (Ahmed et al., 2010) all were used as raw materials for the synthesis of these multiferroics. The nitrates and urea were mixed in desired stoichiometric proportions and dissolved separately in minimum amount of triply distilled water and adding gradually with the mixed solution. The mixture was slowly heated and stirred using a hot plate magnetic stirrer till a self-propagating combustion manner to obtain fluffy powder. The obtained nanopowders were heated at $500^{\circ} \mathrm{C}$ for $4 \mathrm{hrs}$ using a heating/cooling rate of $4^{\circ} \mathrm{C} / \mathrm{min}$.

\section{2. b. Characterization:}

A rich variety of information can be extracted from X-ray Diffraction (XRD) measurements using diffractometer model Proker $\mathrm{D}_{8}$ with $\mathrm{CuK}_{\alpha}$ radiation $\left(\lambda=1.5418^{\circ} \mathrm{A}\right)$ in a wide range of Bragg's angle $\left(20-80^{\circ}\right)$ at room temperature. From the position and shape of the lines, one can obtain the unit cell parameters and micro-structural parameters (crystallite size, micro-strain, etc.) respectively. The relation between the average crystallite size (L-in $\AA$ ) and the full width at half maximum (FWHM-in rad) is given by the Scherrer's formula:

$$
L=\frac{k \lambda}{\beta \cos \theta}
$$

Where, $\lambda$ is $\mathrm{X}$-ray wavelength $=1.54056 \mathrm{~A}, \beta$ is the corrected full width of half maximum $(\mathrm{FWHM})$, and $\mathrm{k}$ is the shape factor constant $=0.89$. X-ray diffraction of these samples was carried out using Philips $\mathrm{Pu} 1390$ channel control Co-k $\alpha$ target and filter Fe of wavelength $(\lambda=1.791 \AA)$ for all samples to assure the formation of the samples. Also from the figure it can be seen that, from Miller indices (hkl) values of the diffraction peaks were referred to hexagonal axes rather than rhombohedral axes where the lattice parameters a and $\mathrm{c}$ are calculated using the equation (Xu et al., 2009).

$$
\frac{1}{d^{2}}=\frac{4}{3}\left[\frac{\left(h^{2}+h k+k^{2}\right)}{a^{2}}\right]+\frac{\ell^{2}}{c^{2}}
$$

Scanning electron microscope (SEM) FEI company- Quanta FEG 250- Holland was used to reveal the surface morphology and microstructure of the prepared samples. The dc magnetic 
susceptibility measurements were carried out using Faraday's method from room temperature up to $700 \mathrm{~K}$ at three different magnetic field intensities $(1340,1660,1990 \mathrm{Oe})$. In this method, a small amount of the powdered sample was inserted in a cylindrical Pyrex glass tube at the point of maximum gradient. The temperature of the samples was measured using T-type thermocouple with junction near the sample to avoid the temperature gradient. In addition, magnetization measurement of the nanoparticles were performed using a vibrating sample magnetometer (VSM; 9600 - 1LDJ; USA) at room temperature.

\section{Results and discussion}

\section{1. Structural properties}

\section{1a. XRD analysis}

Figure (1a) illustrates the XRD patterns for the samples $\mathrm{Bi}_{1-\mathrm{x}-\mathrm{y}} \mathrm{Sr}_{\mathrm{x}} \mathrm{RE}_{\mathrm{y}} \mathrm{FeO}_{3}$; $(\mathrm{BRSFO})$ at $\mathrm{y}=0.03$ and $\mathrm{x}=0.4$ nanomultiferroic system. The XRD patterns are in excellent accord with the powder data $\mathrm{BiFeO}_{3}$ (ICDD card number 86-1518). It is reveal that, the effect of $\mathrm{Bi}$ substitution by $\mathrm{Y}^{3+}$, $\mathrm{Nd}^{3+}, \mathrm{Ce}^{3+}$, and $\mathrm{La}^{3+}$ ions on the structure of BSRFO indicated that generally for all the samples, the second phase of the undoped sample attributed to $\mathrm{Fe}$ or $\mathrm{Bi}$ rich phases, $\mathrm{Bi}_{2} \mathrm{Fe}_{4} \mathrm{O}_{9}$ and $\mathrm{Bi}_{25} \mathrm{FeO}_{40}$ (asterisk in Fig. 1a) were routinely observed as shown in previous results (Kumar et al., 2006). However, the main peaks in the XRD are related to perovskite-structured phases, while the second phase peaks apparently disappear in the XRD data of the doped samples. Besides, RE-doped $\mathrm{BiFeO}_{3}$, all peaks are indexed according to the $\mathrm{R} 3 \mathrm{c}$ cell of $\mathrm{BiFeO}_{3}$. The lattice parameters deduced for pure $\mathrm{BiFeO}_{3}$ hexagonal unit cell were found to have values $\mathrm{a}=$ $5.5795 \AA$ and $\mathrm{c}=13.8359 \AA$.

The presence of rare earth in bismuth strontium ferrites indicates that, the incorporation of $\mathrm{RE}^{3+}$ ions into BSFO lattice crystal structure cause the merging of the two intense diffraction peaks at $31.75^{\circ}$ and $32.06^{\circ}$ which corresponds to the lattice plane (104) and (110) merges and thus the peak shift appears at $32^{\circ}$ as in Fig. (1b). This peak shift occurs due to the structural distortion when doping of smaller ionic radius of $\mathrm{RE}^{3+}\left(\mathrm{Y}^{3+}=0.96, \mathrm{Nd}^{3+}=0.98, \mathrm{Ce}^{3+}=1.07\right.$, and $\mathrm{La}^{3+}=$ $1.16 \AA)$ instead of higher ionic radius $\mathrm{Bi}^{3+}(1.17 \AA)$ ions which were also reported by several authors (Yang et al., 2011, Rojas-George et al., 2014). Rare earth substitution did not affect the crystal orientation of the BSFO ferrites although the peaks have shifted towards higher angle. This suggests that the addition of rare-earth can either eliminate oxygen vacancies or avoid compositional fluctuations of $\mathrm{Fe}^{3+}-\mathrm{Fe}^{2+}$ oxidation state influencing the appearance of secondary phases. These results agree well with Bellakki et al (Bellakki et al., 2010, Mukherjee et al., 2012, Gautam et al., 2012). Moreover, the crystallite sizes were calculated using Scherrer's formula $(\mathrm{L}=0.9 \lambda / \beta \cos \theta)$ for the given $\mathrm{XRD}$ patterns and average crystallite sizes were found to be about 22.43,13.27,14.12, and 21.66 nm for samples $\mathrm{Bi}_{0.57} \mathrm{Sr}_{0.4} \mathrm{Y}_{0.03} \mathrm{FeO}_{3}, \mathrm{Bi}_{0.57} \mathrm{Sr}_{0.4} \mathrm{Nd}_{0.03} \mathrm{FeO}_{3}$, $\mathrm{Bi}_{0.57} \mathrm{Sr}_{0.4} \mathrm{Ce}_{0.03} \mathrm{FeO}_{3}$, and $\mathrm{Bi}_{0.57} \mathrm{Sr}_{0.4} \mathrm{La}_{0.03} \mathrm{FeO}_{3}$, respectively.

Table (1): XRD structure parameters of $\mathrm{Bi}_{0.57} \mathrm{Sr}_{0.4} \mathrm{RE}_{0.03} \mathrm{FeO}_{3} ; \mathrm{RE}=\mathrm{None}, \mathrm{Y}$,

$\mathrm{Nd}, \mathrm{Ce}$, and La nanomultiferroics system.

\begin{tabular}{|c|c|c|c|c|c|c|}
\hline Sample & $\mathbf{r}(\mathbf{n m})$ & $a=b(n m)$ & c (nm) & c/a (nm) & $\mathrm{V}(\mathrm{nm})$ & $\mathbf{L}(\mathbf{n m})$ \\
\hline $\mathrm{Bi}_{0.6} \mathrm{Sr}_{0.4} \mathrm{FeO}_{3}$ & $\mathbf{0}$ & 5.5795 & 13.8359 & 2.4798 & 373.0061 & 25.95 \\
\hline $\mathrm{Bi}_{0.57} \mathrm{Sr}_{0.4} \mathrm{Y}_{0.03} \mathrm{FeO}_{3}$ & 0.96 & 5.5552 & 13.8675 & 2.4963 & 370.6086 & 22.43 \\
\hline $\mathrm{Bi}_{0.57} \mathrm{Sr}_{0.4} \mathrm{Nd}_{0.03} \mathrm{FeO}_{3}$ & 0.98 & 5.6343 & 13.8014 & 2.4495 & 379.4207 & 13.27 \\
\hline $\mathrm{Bi}_{0.57} \mathrm{Sr}_{0.4} \mathrm{Ce}_{0.03} \mathrm{FeO}_{3}$ & 1.07 & 5.5782 & 14.1598 & 2.5384 & 381.5603 & 14.12 \\
\hline $\mathrm{Bi}_{0.57} \mathrm{Sr}_{0.4} \mathrm{La}_{0.03} \mathrm{FeO}_{3}$ & 1.16 & 5.5836 & 13.7915 & 2.47 & 372.33 & 21.66 \\
\hline
\end{tabular}


The lattice parameters were computed on the basis of hexagonal unit cell and reported in Table (1). It is clear that, a clear change in the lattice parameters with ionic radii of the rare earth elements. From the Table, it is indicated that $\mathrm{Y}^{3+}$ ions exhibit the smallest volume.

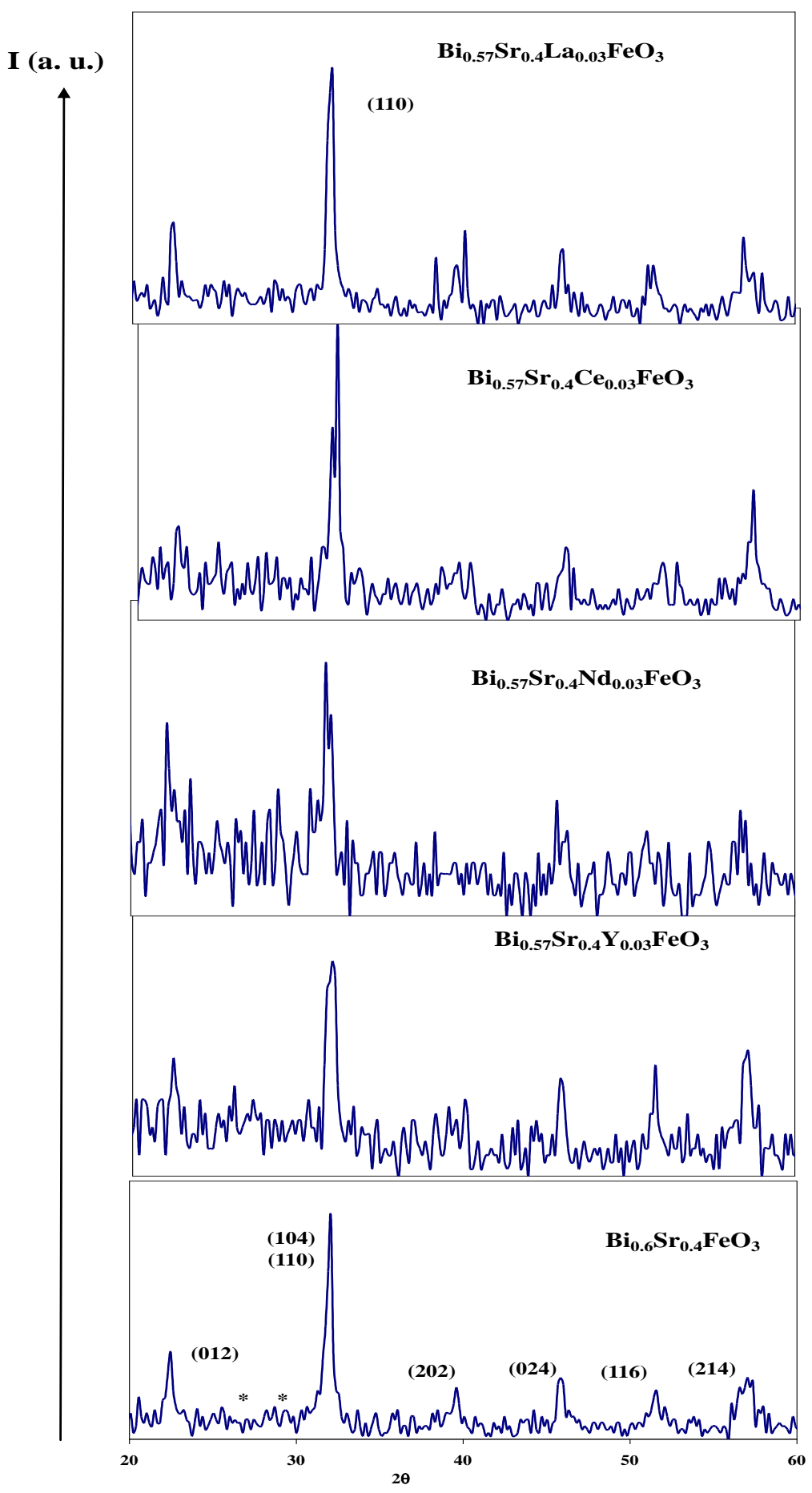

Fig. (1a): XRD patterns of the $\mathrm{Bi}_{0.57} \mathrm{Sr}_{0.4} \mathrm{RE}_{0.03} \mathrm{FeO}_{3}$ nanomultiferroics at different rare earth ions; $\mathrm{RE}=$ None, $\mathrm{Y}^{3+}, \mathrm{Nd}^{3+}, \mathrm{C} e^{3+}$, and $\mathrm{La}^{3+}$ ions. 


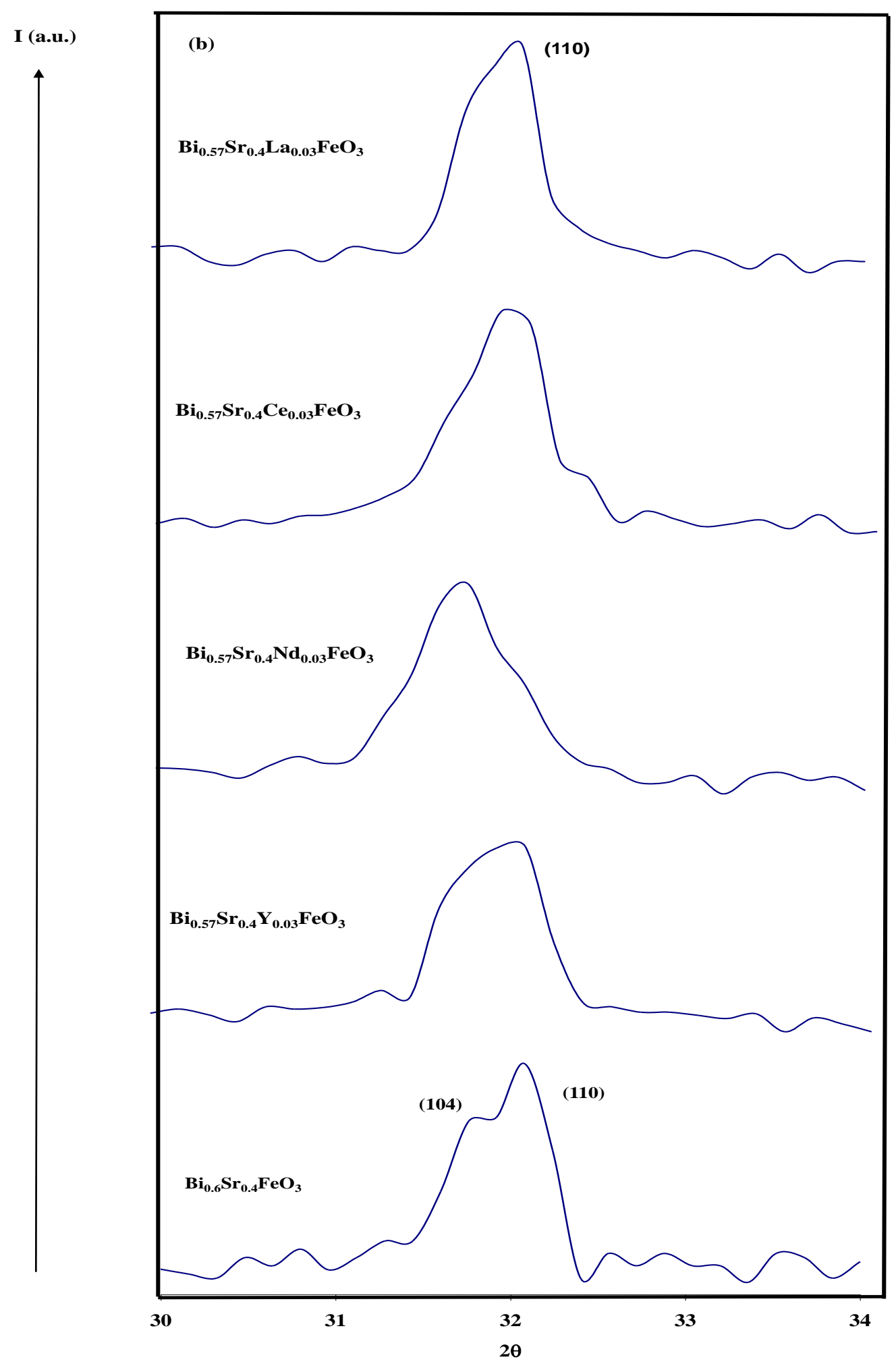

Fig. $(1 \mathrm{~b})$ : The magnified XRD patterns of $\mathrm{Bi}_{0.6} \mathrm{Sr}_{0.4} \mathrm{FeO} \mathrm{O}_{3}$ and in the range of $\mathrm{Bi}_{0.57} \mathrm{Sr}_{0.4} \mathrm{RE}_{0.03} \mathrm{FeO}_{3} 30^{\circ}-34^{\circ}$. 


\section{1b. Microstructural analysis}

The gain understanding of microstructural features of $\mathrm{BSFO}_{3}$ multiferroic rare earth doped samples are shown in Figure (2). SEM of $\mathrm{Bi}_{0.57} \mathrm{Sr}_{0.4} \mathrm{Y}_{0.03} \mathrm{FeO}_{3}, \mathrm{Bi}_{0.57} \mathrm{Sr}_{0.4} \mathrm{Nd}_{0.03} \mathrm{FeO}_{3}$, and $\mathrm{Bi}_{0.57} \mathrm{Sr}_{0.4} \mathrm{Ce}_{0.03} \mathrm{FeO}_{3}$ samples were recorded at room temperature. The microstructures were overall dense with small grains, well-interlinked and randomly arranged through out the sample surfaces besides some of the particles are agglomerated with a high interconnection of grains. In other words, SEM microstructure exhibits clear hexagonal grain growth habit. Doping of RE causes structural distortion as well as suppresses spiral spin structure in BSFO; as a result both ferroelectric and ferromagnetic properties get enhanced. It is quite noted that the grain size shape and/or distribution is affected strongly by the ionic radius of the A cation.
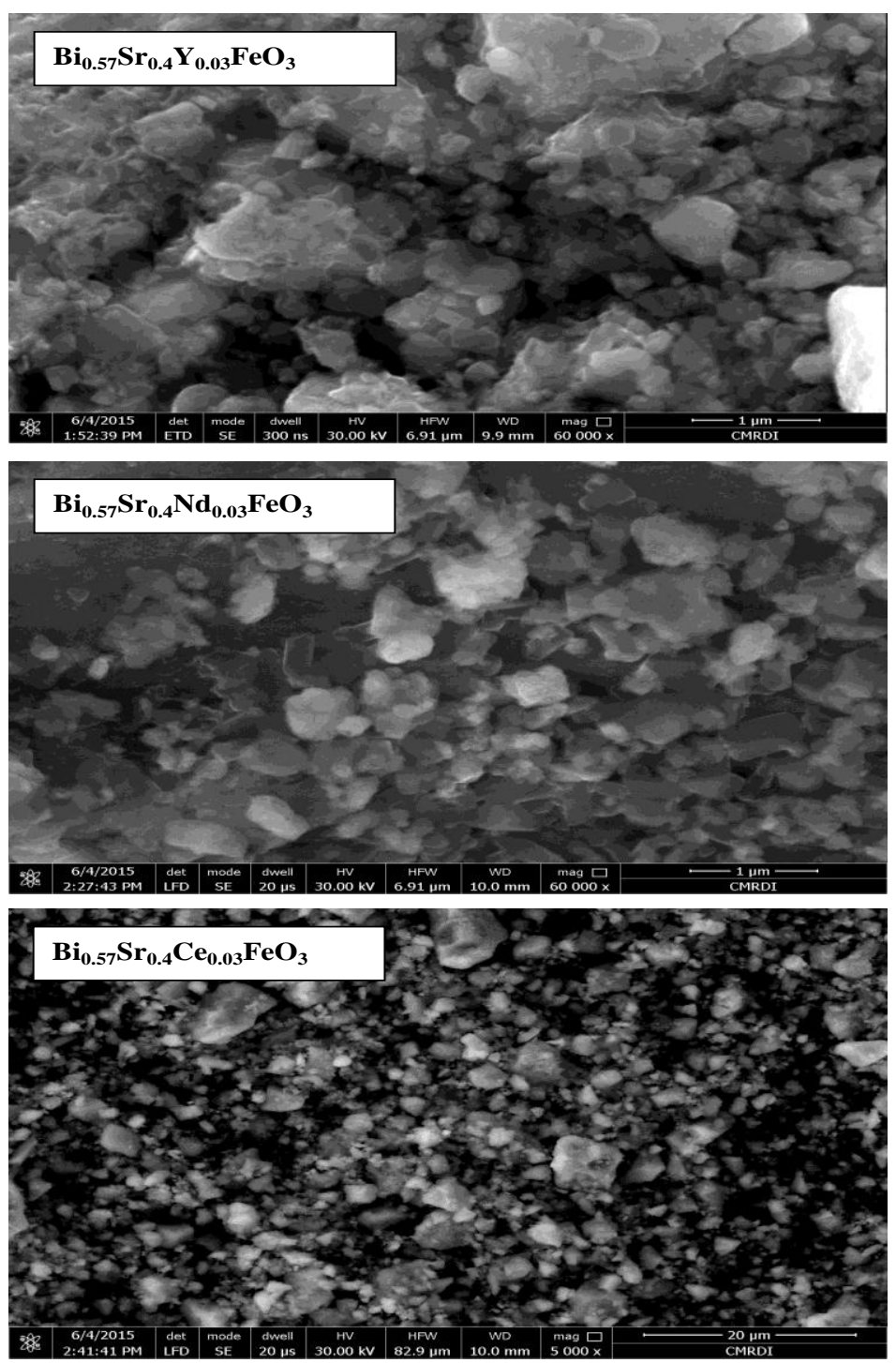

Fig. (2): Typical SEM images of $\mathrm{Bi}_{0.57} \mathrm{Sr}_{0.4} \mathrm{RE}_{0.03} \mathrm{FeO}_{3}$ nanomultiferroic system; $R E=Y^{3+}, \mathrm{Nd}^{3+}$, and $\mathrm{Ce}^{3+}$ ions. 


\subsection{Magnetic Properties:}

\section{2. a. Magnetic Susceptibility:}

The dependence of the dc molar magnetic susceptibility $\left(\chi_{\mathrm{M}}\right)$ on the absolute temperature as a function of the magnetic field intensity is illustrated in Figure (3) for the undoped and doped multiferroic samples $\mathrm{Bi}_{0.57} \mathrm{Sr}_{0.4} \mathrm{RE}_{0.03} \mathrm{FeO}_{3} ; R E=\mathrm{Y}^{3+}, \mathrm{Nd}^{3+}, \mathrm{Ce}^{3+}$, and $\mathrm{La}^{3+}$ ions. In multiferroic, there are two magnetic sublattices: one for the iron ions and the other for the rare earth. In our case, $\mathrm{RE}^{3+}$ ions have a paramagnetic character. Therefore, the contribution of the magnetic properties is controlled by the iron sublattice represented by $\left\langle\mathrm{FeO}_{6}\right\rangle$ octahedron at temperature above room. While the contribution of the rare earth element in the magnetic properties originated from the $4 \mathrm{f}$ electrons of the lanthanide. This would be clarified and emphasized at low temperature. The data shows that all investigated samples were G-type antiferromagnetic with a slight canting resulting in a weak ferromagnetic moment. Besides, the magnetic susceptibility decreases with increasing magnetic field for all samples. This is because the magnetic susceptibility is inversely proportional to the magnetic field according to $\chi_{\mathrm{M}}=M / H$. The contribution to the Néel temperature $\left(\mathrm{T}_{\mathrm{N}}\right)$ was due to the superexchange interaction between antiferromagnetically coupled $\mathrm{Fe}^{3+}$ ions $\left(\mathrm{Fe}^{3+}-\mathrm{O}^{2-}-\mathrm{Fe}^{3+}\right)$ through the oxygen anions. Different values of $\chi_{M}$ and $T_{N}$ were obtained for the different samples and reported in Table (2). For all samples, $\chi_{M}$ decreases slowly with increasing temperature until reaching $\mathrm{T}_{\mathrm{N}}$. Moreover, from the Table it is clear that, the values of $\chi_{M}$ changed with the ionic radius of the doping ion at room temperature where $\mathrm{Bi}_{0.57} \mathrm{Sr}_{0.4} \mathrm{Y}_{0.03} \mathrm{FeO}_{3}$ has the highest magnetization $(0.26 \mathrm{emu} / \mathrm{g})$ while $\mathrm{Bi}_{0.57} \mathrm{Sr}_{0.4} \mathrm{La}_{0.03} \mathrm{FeO}_{3}$ has the smallest magnetization $(0.08 \mathrm{emu} / \mathrm{g})$. As the ionic radii change, the values of $\mu_{\text {eff }}, T_{N}$, and $\chi_{\mathrm{M}}$, are changed and the optimum rare earth has the most enhanced physical properties is $\mathrm{Bi}_{0.57} \mathrm{Sr}_{0.4} \mathrm{Y}_{0.03} \mathrm{FeO}_{3}$ and $\mathrm{Bi}_{0.57} \mathrm{Sr}_{0.4} \mathrm{Nd}_{0.03} \mathrm{FeO}_{3}$. Finally we can conclude that the, Yttrium and Neodynium doped BSFO possesses improved multiferroic properties which makes it suitable for electromagnetic device applications.

The variation of magnetic parameters such as Néel temperature $\left(T_{N}\right)$, magnetic susceptibility $\left(\chi_{\mathrm{M}}\right)$, and effective magnetic moment $\left(\mu_{\mathrm{eff}}\right)$ as a function of different doped rare earth $\mathrm{Bi}_{0.57} \mathrm{Sr}_{0.4} \mathrm{RE}_{0.03} \mathrm{FeO}_{3}$ nanomultiferroics; $\mathrm{RE}=\mathrm{Y}^{3+}, \mathrm{Nd}^{3+}, \mathrm{Ce}^{3+}$, and $\mathrm{La}^{3+}$ ions , is shown in Fig. (4: a-c). The antiferromagnetic transition temperature $\left(\mathrm{T}_{\mathrm{N}}\right)$ was identified and shown and listed in Table (2). It is clear that, the highest value of $\left(\mathrm{T}_{\mathrm{N}}\right)$ at $\mathrm{Bi}_{0.57} \mathrm{Sr}_{0.4} \mathrm{Y}_{0.03} \mathrm{FeO}_{3}(710 \mathrm{~K})$ and the smallest $\mathrm{T}_{\mathrm{N}}$ at $\mathrm{Bi}_{0.57} \mathrm{Sr}_{0.4} \mathrm{Ce}_{0.03} \mathrm{FeO}_{3}(530 \mathrm{~K})$. This variation is due to the different ionic radius of the dopant elements. The change in the Néel temperature with ionic radii of the doping different ions is directly correlated with the change of Fe-O-Fe angle $(\theta)$. This angle controls the superexchange interaction between antiferromagnetically coupled Fe cations through oxygen anions. 

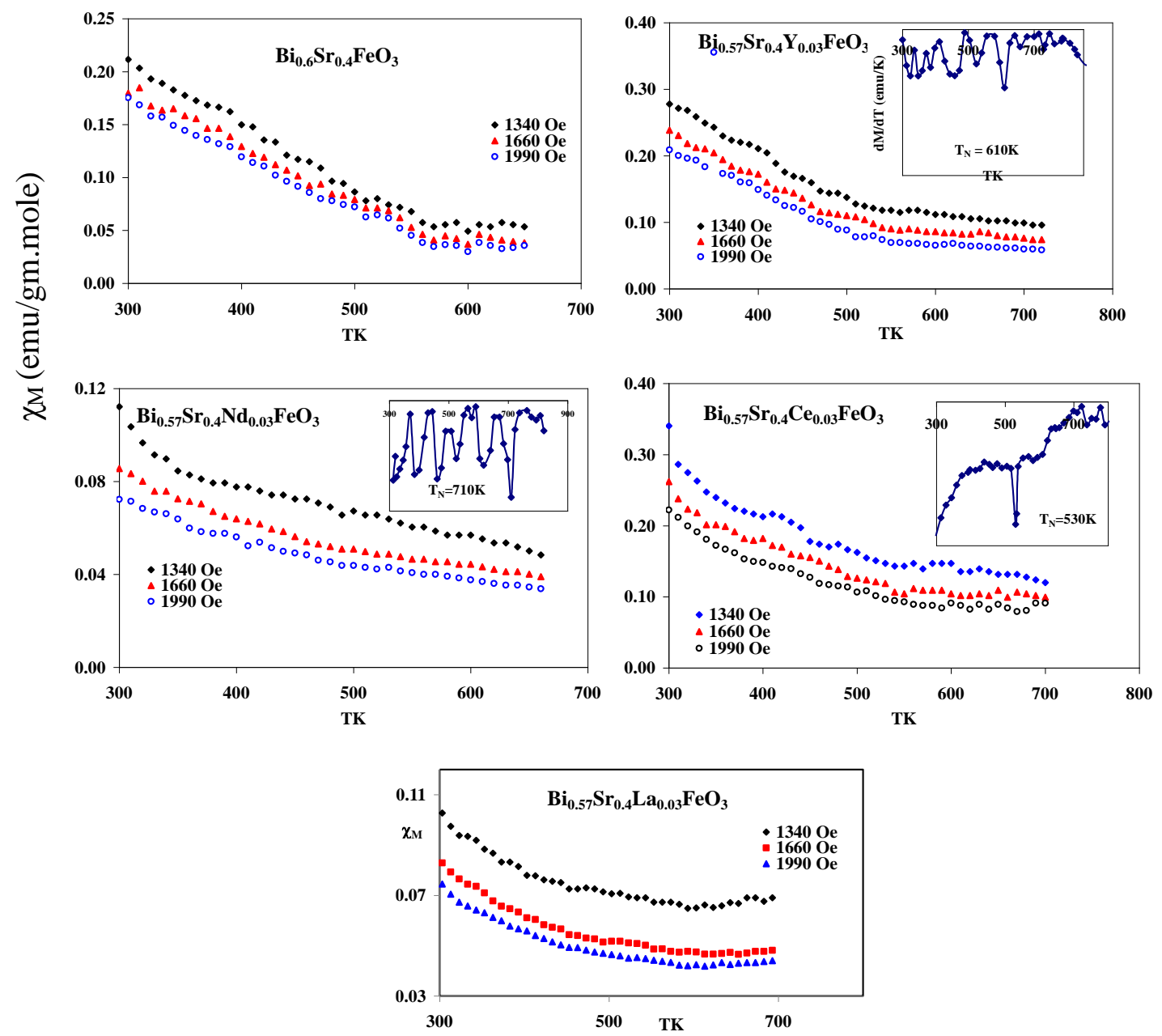

Fig. (3): The variation of magnetic susceptibility $\left(\chi_{M}\right)$ at different ionic radius of $R E$ for $\mathrm{Bi}_{0.67} \mathrm{Sr}_{0.4} \mathrm{RE}_{0.03} \mathrm{FeO} \mathrm{O}_{3}$ nanomultiferroics; $\mathrm{RE}=$ None, $\mathrm{Y}^{3+}, \mathrm{Nd}^{3+}, \mathrm{Ce}^{3+}$, and $\mathrm{La}^{3+}$ ions.

Table (2): Effect of ionic radius of $R E^{3+}$ ions on the magnetic parameters of $\mathrm{Bi}_{0.57} \mathrm{Sr}_{0.4} \mathrm{RE}_{0.03} \mathrm{Fe} \mathrm{O}_{3}$ nanomultiferroic system; $\mathrm{RE}=\mathrm{None}, \mathrm{Y}^{3+}, \mathrm{Nd}^{3+}, \mathrm{Ce}^{3+}$, and $\mathrm{La}^{3+}$ ions.

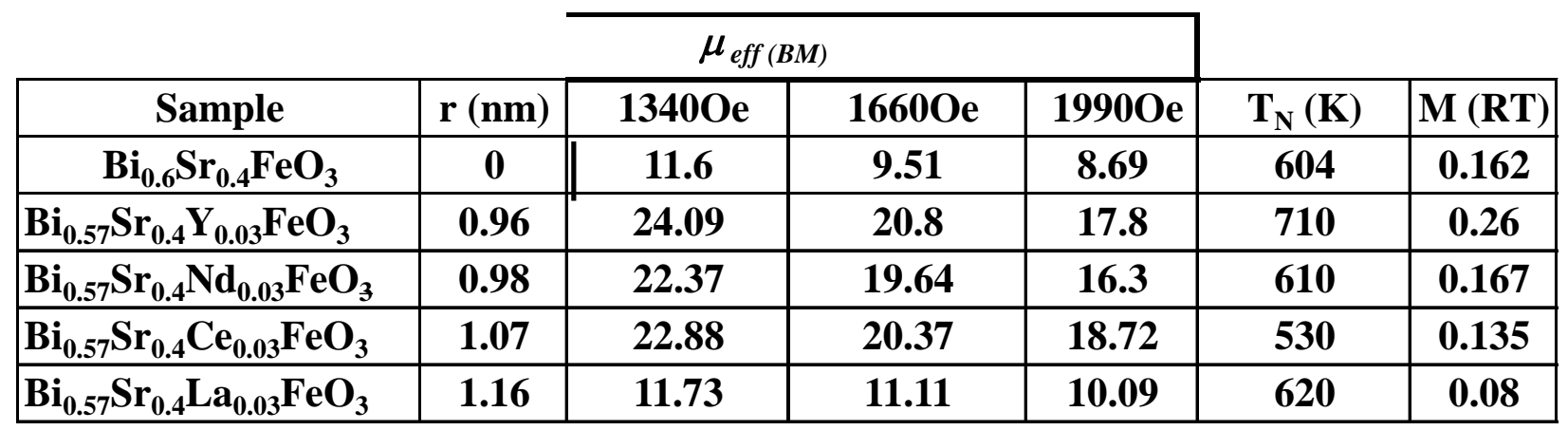



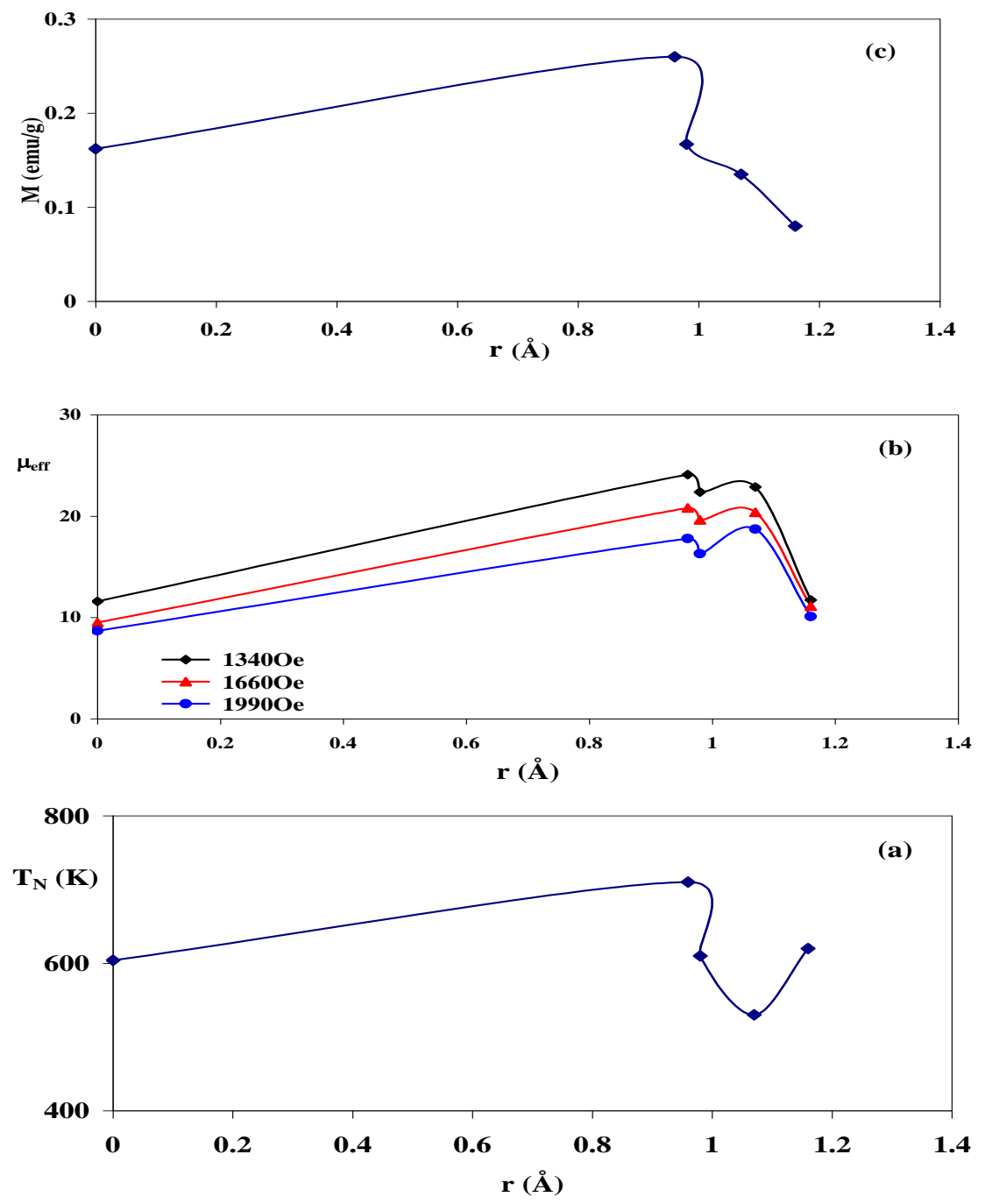

Fig. ( $4: a-c):$ a) Dependence of $R E$ ionic radius $(r)$ on; a) Néel temperature $\left.\left(T_{N}\right), b\right)$ Variation of the effective magnetic moment $\left(\mu_{\text {eff }}\right)$ . and c) Devendence of magnetization (M).

\section{2 b. Hystersis Loops and magnetization:}

The magnetization versus applied magnetic field $(\mathrm{M}-\mathrm{H})$ loops for all investigated samples measured at $300 \mathrm{~K}$ for pure and doped $\mathrm{Bi}_{0.57} \mathrm{Sr}_{0.4} \mathrm{RE}_{0.03} \mathrm{FeO}_{3}$ nanomultiferroics; $\mathrm{RE}=\mathrm{Y}^{3+}, \mathrm{Nd}^{3+}$, $\mathrm{Ce}^{3+}$, and $\mathrm{La}^{3+}$ ions are shown in Fig. (5). It is clear that, all the loops confirm weak ferromagnetic behavior, which is greatly enhanced for doped samples (Table 3). Saturation level of loops is also improved. $\mathrm{BiFeO}_{3}$ having G-type antiferromagnetic spin ordering, shows weak magnetism due to spin canting from perfect antiparallel direction by symmetry. The improvement in magnetic behavior can be explained as follows: the spin cycloid structure of BSFO may be disturbed due to change in $\mathrm{Fe}-\mathrm{O}-\mathrm{Fe}$ angle on incorporation $\mathrm{RE}^{3+}$ ion in BSFO lattice and/ or RE-O-Fe like spin coupling between rare earth-transition metal ions (Li et al., 2007). Further, increment in magnetization on $\mathrm{RE}^{3+}$ ion doping may be attributed to ferrimagnetic like super-exchange interaction between $\mathrm{RE}^{3+}$ and $\mathrm{Fe}^{3+}$ ions due to the difference in their magnetic moments (Minh et al., 2010, Safi et al., 2012). 


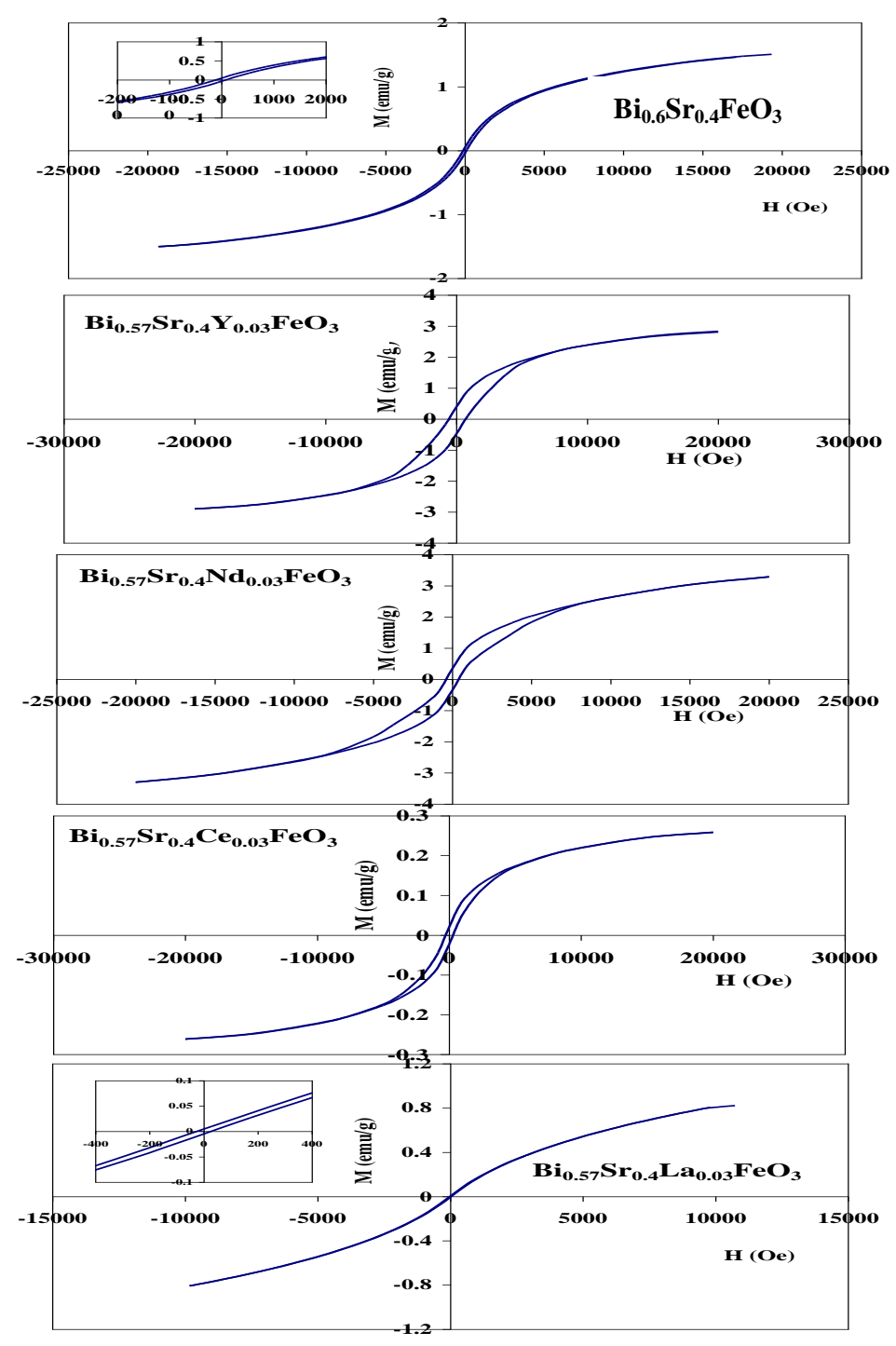

Fig. (5): Hystersis loop for $\mathrm{Bi}_{0.57} \mathrm{Sr}_{0.4} \mathrm{RE}_{0.03} \mathrm{Fe} \mathrm{O}_{3}$ nanomultiferroics at different ionic radius of $\mathrm{RE}=$ None, $\mathrm{Y}^{3+}, \mathrm{Nd}^{3+}, \mathrm{Ce}^{3+}$, and $\mathrm{La}^{3+}$ ions.

In other words, it is observed that, the hysteresis curves plots at all the samples unsaturated M-H behavior of the solid solutions suggest their antiferromagnetic nature with weak ferromagnetism. The values of saturation magnetization $\left(M_{s}\right)$, the remanent magnetization $\left(M_{r}\right)$, and coercive field $\left(\mathrm{H}_{\mathrm{c}}\right)$ of the investigated samples are summarized in Table (3) indicated that, the values of these parameters change with different $\mathrm{RE}$ ions where, $\mathrm{Bi}_{0.57} \mathrm{Sr}_{0.4} \mathrm{Nd}_{0.03} \mathrm{FeO}_{3}$ has higher saturation magnetization $(3.31 \mathrm{emu} / \mathrm{g})$ than the undoped sample $(0.24 \mathrm{emu} / \mathrm{g})$ and has highest magnetic moment $\eta_{\text {в }}(0.163)$ while undoped sample has $\eta_{\text {в }}(0.012)$. This indicated that, Bismuth ferrite is antiferromagnetic, but although each $\mathrm{Fe}^{3+}$ ion is surrounded by six other $\mathrm{Fe}^{3+}$ ions with opposite angular magnetic spin directions, their spins do not annul completely, so there are some resulting magnetic moments. These moments have cycloidal ordering with period of around $64 \mathrm{~nm}$, which means that particles smaller than $64 \mathrm{~nm}$ are weakly ferromagnetic (Catalan et al., 2009, Lebeugle et al., 2007). Besides, the hysteresis loop shows a small but nonzero remnant magnetization (Mr). The spontaneous magnetization should result from the spiral magnetic ordering partially destroyed in the BSFO ferrite (Anthonyraj et al., 2013, Haiyang et al., 2012). The magnetization curve of $\mathrm{Bi}_{0.6} \mathrm{Sr}_{0.4} \mathrm{FeO}_{3}(\mathrm{RE}=0.0)$ multiferroic showing antiferromagnetic 
behavior has been reported earlier. Whereas $\mathrm{Bi}_{0.57} \mathrm{Sr}_{0.4} \mathrm{RE}_{0.03} \mathrm{FeO}_{3}\left(\mathrm{RE}=\mathrm{Y}^{3+}, \mathrm{Nd}^{3+}, \mathrm{Ce}^{3+}\right.$, and $\mathrm{La}^{3+}$ ions) exhibit a weak ferromagnetism, with remnant magnetization $\left(\mathrm{M}_{\mathrm{r}}\right)$ values of $0.43,0.39$, 0.38 , and $0.046 \mathrm{emu} / \mathrm{g}$ respectively. These values are higher than that of undoped BSFO $(0.037$ emu/ g) sample. The values of $\mathrm{M}_{\mathrm{r}}$ increase with $\mathrm{Y}^{3+}$ ions because $\mathrm{RE}^{3+}$ ions substitution can suppress or destroy the space, modulated cycloidal spin structure of RE : BSFO multiferroic. The other factor, which could be responsible for increase in $M_{r}$ with substitution, is size effect (Lee et al., 2006). The considerable increase in the remnant magnetization could result from improved crystallinity and a lack of secondary phases in these multiferroics. Several reasons contributing to the weak ferromagnetism in RE : BSFO multiferroics have been reported: (1) The enhanced magnetization with doping $\mathrm{RE}^{3+}$ ions is mainly attributed to the gradual collapse of the space modulated spin structure (Park et al., 2007) together with the increased degree of canting and magnetic interactions between magnetic ions giving rise to long range canted antiferromagnetic order. (2) The higher remnant magnetization in the Y: BSFO may also be attributed to the spin interaction between $\mathrm{Y}^{3+}$ and $\mathrm{Fe}^{3+}$ or $\mathrm{Fe}^{2+}$ ions (Park et al., 2007). (3) The particle size (or) crystallite size also plays a role in enhancing magnetization. The reduced particle size modified the long range spiral order (Xu et al., 2013). Furthermore from the Table it is clear that, all the samples have coercivity (Hc) higher than undoped sample except $\mathrm{Bi}_{0.57} \mathrm{Sr}_{0.4} \mathrm{La}_{0.03} \mathrm{FeO}_{3}$ while $\mathrm{Bi}_{0.57} \mathrm{Sr}_{0.4} \mathrm{Y}_{0.03} \mathrm{FeO}_{3}$ multiferroic has the highest coercive field $\left(\mathrm{H}_{\mathrm{c}}\right)$ of 635.9 Oe which higher five times on the undoped sample (163.44 Oe). According to the above results, the high coercivity is related to different contribution of the total anisotropy as well as the spin- orbit coupling in different rare earth elements. The low symmetry of crystal will lead to strong magnetocrystalline anisotropy, which is a plausible explanation reason for dopes samples to have high coercivity relative to the undoped sample.

In other words, there are other factors that affect the magnetization of $\mathrm{BSRFO}_{3}$ nanoparticles such that:

(i) The canted spin structure of $\mathrm{LaFeO}_{3}$ gives rise to a weak ferromagnetism.

(ii) Oxygen nonstoichiometry could change the valence state of some of $\mathrm{Fe}^{3+}$ ions which alter the magnetization. The formation of $\mathrm{Fe}^{2+}$ was reported to play a role in improving the magnetization of nanoscale $\mathrm{BiFeO}_{3}$.

(iii) Structural defects, broken exchange bonds and a small number of atomic neighbors induce a Table (3): Magnetization parameters for the nanomultiferroics $\mathrm{Bi}_{0.57} \mathrm{Sr}_{0.4} \mathrm{RE}_{0.03} \mathrm{FeO}_{3}$; at different ionic radius of $\mathrm{RE}=\mathrm{None}, \mathrm{Y}^{3+}, \mathrm{Nd}^{3+}, \mathrm{Ce}^{3+}$, and $\mathrm{La}^{3+}$ ions.

\begin{tabular}{|c|c|c|c|c|c|c|c|}
\hline Sample & $\mathbf{r}(\mathrm{nm})$ & $M_{s}($ emu/g) & $M_{r}(\mathrm{emu} / \mathrm{g})$ & $\mathrm{H}_{\mathrm{C}}(\mathrm{Oe})$ & $R=M_{r} / M_{s}$ & M.WT & $\eta_{B}$ \\
\hline $\mathrm{Bi}_{0.6} \mathrm{Sr}_{0.4} \mathrm{FeO}_{3}$ & $\mathbf{0}$ & 0.24 & 0.037 & 163.44 & 0.154 & 276.42 & 0.012 \\
\hline $\mathrm{Bi}_{0.57} \mathrm{Sr}_{0.4} \mathrm{Y}_{0.03} \mathrm{FeO}_{3}$ & 0.96 & 2.87 & 0.43 & 635.9 & 0.152 & 272.81 & 0.140 \\
\hline $\mathrm{Bi}_{0.57} \mathrm{Sr}_{0.4} \mathrm{Nd}_{0.03} \mathrm{FeO}_{3}$ & 0.98 & 3.31 & 0.35 & 403.06 & 0.105 & 274.48 & 0.163 \\
\hline $\mathrm{Bi}_{0.57} \mathrm{Sr}_{0.4} \mathrm{Ce}_{0.03} \mathrm{FeO}_{3}$ & 1.07 & 0.56 & $2.20 \mathrm{E}-02$ & 282.35 & 8.39E-02 & 274.35 & 0.028 \\
\hline $\mathrm{Bi}_{0.57} \mathrm{Sr}_{0.4} \mathrm{La}_{0.03} \mathrm{FeO}_{3}$ & 1.16 & 0.11 & 0.046 & 25.95 & 0.418 & 274.32 & 0.005 \\
\hline
\end{tabular}

The $\mathrm{Nd}^{3+}$ doped sample reveals largest coercivity, i.e. 2.4 times which of the undoped one which is may be due $4 \mathrm{f}-3 \mathrm{~d}$ coupling. So, the changes of these parameters are due to the increase in the 
anisotropy and the change in the particle shape and size as clarified in the XRD discussed before. Overall, the increase in both remanence $\left(M_{r}\right)$ and saturation magnetization $\left(M_{s}\right)$ is associated with the variation of the A-site cation radius by $\left(\mathrm{RE}^{3+}\right)$ and is interpreted as due to structural distortions in the $\left\langle\mathrm{FeO}_{6}\right\rangle$ octahedron. It is clear that, almost systematic variation of these parameters with the ratio c/a means that the lattice distortion has played an important role in the control of the magnetization of new multiferroics.

\section{Conclusion}

Substitution of small amount of $\mathrm{La}^{3+}, \mathrm{Ce}^{3+}, \mathrm{Nd}^{3+}$, and $\mathrm{Y}^{3+}$ ions for $\mathrm{BiSrFeO}_{3}$ nanomultiferroics is seen to improve both the magnetization and the dielectric constant as following:

- Secondary phases observed in pure BFO are significantly suppressed in the substituted samples and no structural transition is observed with co-substitution and the rare earth doping improves the particle morphology.

- Rare earth doping on BSFO was successful achieved.From the above mentioned results, it is concluded that, RE doping with tiny content alters structural and magnetic properties.

- Magnetization improvement was achieved at different levels including strenthing the saturation magnetization and suppression of the AF caracter on the expense of the ferromagnetic one.

- The coercivity was increased depending strongly on the RE ion used, in view of the $4 \mathrm{f}$ electron and ionic radius based on our finidings, this nanomultiferrois samples are recommended to be used in spintronic applications.

- The enhancement of saturation magnetization for the $\mathrm{Nd}^{3+}$ ion doping may be attributed to its great amount of $\mathrm{Fe}^{2+}$ and suppressed periodic self-spinning structure. These changes in the magnetic properties could be more useful in terms of the use of RE doped BSFO nanomultiferroics for magneto optic applications and in addition these results suggest that the improved magnetic property in the BSFO systems could push the rare earths dopant toward multiferroic applications.

- The structural distortion causes increase in canting angle and variation of $\mathrm{Fe}^{2+}$ ion can also lead to increased magnetization. Meaning that the, yttrium doped BSFO possesses enhanced photocatalytic activity along with multiferroic properties which makes it suitable for device applications.

- To make BSREFO implement able in device fabrication, yttrium doping is a very effective strategy. The lattice distortion caused by doping is one of the principal causes behind the enhancement in multiferroic properties.

\section{Acknowledgments}

I would like to express my sincere gratitude to my dear advisor Prof. Dsc. Dr. M. A. Ahmed. It was his guidance and support that helped me through all the difficult time. I will surely benefit from his creative thoughts, suggestions and dedication throughout the rest of my life. 


\section{References}

Ahmed. M. A., Okasha. N., El-Dek. S. I., Nanotechnology, 19: 065603(2008).

Ahmed. M. A., Magn. J., Magn. Mater, 322: 763(2010).

Ahn. CH., Rabe. KM., Triscone. JM., J. Science; 303: 488-491 (2004).

Anthonyraj. C., Muneeswaran. M., Jegatheesan. P., Giridharan. N. V., Sivakumar. V., Senguttuvan . G., J. Mater. Sci.: Mater. Electron., 24: 4148 (2013).

Bai. F., Wang. J., Wutting. M., Li. J. F., Wang. N., Pyatakov. A., Zvezdin. A. K., Cross. L. E., Viehland. D., Appl. Phys. Lett., 86: 032511(2005).

Bellakki. M. B., \& Manivannan. V., Journal of Sol-Gel Science and Technology, 53: 184 (2010).

Bhushan. B., Wang. Z., Tol . J., Dalal. NS., Basumallick. A., Vasanthacharya. NY., J. Am. Ceram. Soc., 95: 92 (2012).

Cheong. S. W., Mostovoy. M., Nat. Mater., 6: 13 (2007).

Catalan. G., Scott. J. F., Adv. Mater., 21: 2463 (2009).

Eerenstein. W., Mathur. N.D., Scott. J.F., Nature (London)., 442: 759 (2006).

Ederer. C., Spaldin. N.A., Phys. Rev. B., 71: 060401(2005).

Gruverman. A, Kholkin. A., Rep Prog Phys; 69: 2443- 2474 (2006).

Gao. F, Chen. X, Yin. K, Dong. S, Ren. Z, Yuan. F, Yu. T, Zou. Z \& Liu. JM., Adv Mater, 19: 2889 (2007).

Gautam. A., Uniyal. P., Yadav. K. L. \& Rangra. V. S., Journal of Physics and Chemistry of Solids, 73: 188 (2012).

Hunpratub. S., Thongbai. P., Yamwong. T., Yimnirun. R., Maensiri. S., Appl. Phys. Lett. 94 062904 (2009).

Hill. N. A., J. Phys. Chem. B, 104: 6694 (2000).

Haiyang. D., Zhenping. C., Tao. L., Yong. L., J. Rare Earth., 30: 1123 (2012).

Jiang. Q.H., Liu. F.T., Nan. C. W., Lin. Y.-H., Reece. M.J., Yan. H.X., Ning. H.P., Shen. Z.J., Appl. Phys. Lett., 95: 012909 (2009). 
Kumar. M. and Yadav. K., J. Phys.: Condens. Matter, 18: L 503 (2006).

Kadam. SL, Patankar. KK, Kanamadi. CM, Chougule. BK., Bull Mater., 39: 2265 (2004).

Lahmar. A., Habouti. S., Dietze. M., Solterbeck. C.-H., Es-Souni. M., Appl. Phys. Lett. 94: 012903 (2009).

Lee. D., Kim. M.G., Ryu. S., Jang. H.M., Lee. S.G., Appl. Phys. Lett. 86: 222903 (2005).

Li. S., Jing. L. \& Fu. W., Yang. L., Xin. B. \& Fu. L., Mater Res Bull, 42: 203 (2007).

Li. J-B, Rao. GH, Liang. JK, Liu. YH, Luo. J, Chen. JR., Appl. Phys. Lett., 90: 162513 (2007).

Lebeugle. D., Colson. D., Forget. A., Viret. M., Bonville. P., Marucco. J.F., Fusil. S., Phys. Rev. B, 76: 024116 (2007).

Lee. Y. H., Wu. J. M., Lai. C. H., Appl. Phys. Lett., 88: 042903 (2006).

Lines. M. E., Glass. A. M., , Oxford (1977).

Mukherjee. A., Banerjee. M., Basu. S., Nguyen. T. K. T., Green. L.A.W., Pal. M., Physica B, 448: 199 (2014).

Mukherjee. A., Hossain. S. M., Pal. M., \& Basu. S., Applied Nanoscience. DOI 10.1007/s13204: 0114-8 (2012).

Mahajan. RP., Patankar. KK., Kothale. MB., Patil. SA., Bull Mater. 23: 273 (2000).

Minh. N. V. and Thang. D. V., Journal of Alloys and Compounds, 505: 619 (2010).

Palai. R., Katiyar. R. S., Schmid. H., Tissot. P., Clark. S. J., Robertson. J., Redfern. S. A. T., Catalan. G., and Scott. J. F., Phys. Rev. B, 77 (1): 014110-11 (2008).

Park. T. J., Papaefthymiou. G. C., Viescas. A. J., Moodenbaugh. A. R., Wong. S. S., J Mater Sci: Mater Electron, 7: 766 (2007).

Rojas-George, G, Silva, J, Castañeda, R, Lardizábal, D,Graeve, O.A, Fuentes L, et al. J. Mater. Chem. Phys., 146: 73 (2014).

Rao. G. V. S., Rao. C. N. R., and Ferraro. J. R., Appl. Spectrosc., 24 (4): 45 (1970).

Smolenskii. G.A., Chupis. L., Sov. Phys. USP, 25: 475 (1982).

Singh. A., Pandey. V., Kotnala. R. K., Pandey. D., Phys. Rev. Lett., 101: 247602 (2008). 
Sosnowska. I., Peterlin-Neumaier. T., Steichele. E., J. Phys. C, 115: 4835 (1982).

Slimani Tlemcani. T., El Bahraoui. T., Taibi. M., Belayachi. A., Schmerber. Dinia. G., A., Abd- Lefdil. M., J. Sol- Jel Sci. Technol., 37: 673 (2015).

Safi. R., Shokrollahi. H., J. Solid State Chem., 40: 6 (2012).

Tü tü ncï. H. M. and Srivastava. G. P., J. Phys. Rev. B, 78 (23): 10 (2008).

Uchino. K., Ferroelectric devices, (2000).

Wang. J., Neaton. J. B., Zheng. H., Nagarajan. V., Ogale. S. B., Liu. B., Viehland. D., Vaithyanathan. V., Schlom. D. G., Waghmare. U. V., Spaldin. N. A., Rabe. K. M., Wuttig. M.,Ramesh. R., Science, 299: 1719 (2003).

Wang. Y., Nan. C.W., Appl. Phys. Lett., 89: 052903 (2006).

Wang. A. Q., Souza. N. D', and Golden. T. D., Appl. Clay Sci., 42: (1-2) 7 (2008).

Xu. J., Wang. G., Wang. H., Ding. D., and He. Y., Mater. Lett., 63: 855 (2009).

Xu. X., Guoqiang. T., Huijun. R., Ao. X., J. Ceram. Int., 39: 6223 (2013).

Yang. J., Li. X., Zhou. J., Tang. Y., Zhang. Y., Li. Y., J. Alloys Compd., 509: 7 (2011).

Zhang. X. Y., Song. Q., Xu. F., Ong. C. K., Appl. Phys. Lett., 94: 022907 (2009). 


\section{ملخص البحث باللغة العربية}

دراسة مقارنة لتأثير أيونات عناصر ارضية نادرة مختلفة على متراكب بيزموتـ استرنشوم النانوفيريت

$$
\text { محمد على أحمد 1، - نجوى عكاشة مر اد2، مرفت محمد عبد العال2، مها أيمن حمدى3 }
$$

1. الفيزياء و النانوتكنولوجى- كلية العلوم- جامعة القاهرة.

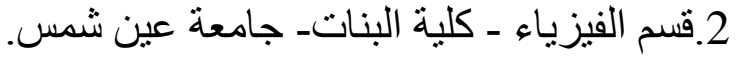

3.قسم الفيزياء ــ الجامعة الالمانية.

فى هذا البحث تمث دراسة تأثير تغير نصف القطرلمجموعة من العناصر الارضية النادرة ( اتريوم، انديوم، سيزيوم، لانثانيوم) على الخواص التركيبة والمغناطيسية للمتر اكب النانومترى بزموت/ استرونشوم.

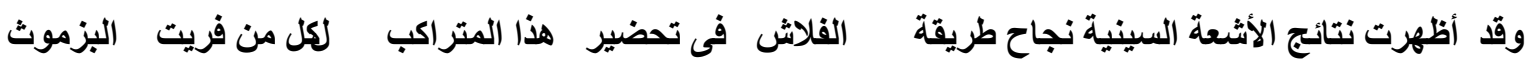
والاسترانشيوم فى طور أحادى بلون أى أطوار ثانوية أخرى وتحضير المتراكب من كلا منهما فى طور و واحد بشكل واضح ودقيق، كما اثبتث النتائج تكوين الجسيمات فى حجم النانو كما أظهر الميكروسكوب الاكترونى الماسح، تكوين التركيزات على شكل سداسي ( hexagonal ). كما اثبتت النتائج التحسن فى الخواص المغناطيسية للمتراكب بعد اضافة العناصر الارضية النادرة حيث كان العزم المغتاطيسى المؤثر للمتركبات التى تحتوى عناصر نادرة ضعف المتراكب الأى لا يحتوى أى

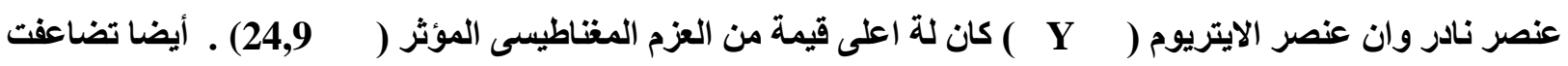
مغناطيسية التثبع بعد اضافة العناصر الارضية النادرة وكانت أعلى قيمة فى وجود عنصر الانديوم ( Nd ) م التى تضاعفت 14 مرة عن العينة التى تخلو من العناصر الارضية النادرة. ونستتنج من هذة النتائج، أن اضافة العناصر الارضية النادرة الى متراكب البزموث والاسترانشيوم ق حسنت من الخواص التركيبية والمغناطيسية للمتراكبات وزادت من معاملاتها المغناطيسية والتى تؤهلها للتطبيقات والاستخدام في 